Journal of Development Economics 5 (1978) 191-193. North-Holland Publishing Company

\title{
EXPORTS AND GROWTH
}

\author{
An empirical re-investigation \\ Peter S. HELLER \\ International Monetary Fund, Washington, DC, U.S.A. \\ Richard C. PORंTER \\ University of Michigan, Ann Arbor, MI 48114, U.S.A.
}

Received June 1977

The hypothesis which Michael Michaely (1977) wanted to test, as have many others before him, was that 'a rapid growth of exports accelerates the economy's growth.' He complained that his predecessors in this task had erred because they correlated the growth rate of national product with the growth rate of exports and, 'since exports are themselves part of the national product, ... a positive correlation of the two variables is almost inevitable, whatever their true relationship' [Michaely $(1977$, p. 50$)]$. His point is well taken; unfortunately, his test commits the same error. In this note, we show the error and provide a correct empiricell test of the hypothesis.

The GNP $(Y)$ of any country is identicaily equal to the sum of its domestically produces internal final demand $(F)$ and its exports $(X):^{1}$

$$
\boldsymbol{Y}=\boldsymbol{F}+\boldsymbol{X}
$$

With derivatives and some manipulation, this identity can be converted into an identity relating growth rates:

$$
y-p=[1-(X / Y)](f-p)+(X / Y)(x-p),
$$

where each lower-case letter represents the per annum growth rate of the corresponding capital-Jetter symbol and $p$ is the population growth rate. ${ }^{2}$ Michaely's criticism, seen in eq. (2), is that any change in the rate of growth

${ }^{1} F$ is usually written out as $(C+I+G-M)$, but the components are not important here. We do issume, for simplicity, that no imports are exported, either as final goods thenselves or ent odied in la er-stage output.

${ }^{2} \mathrm{~A} 11$ variables are here shown in per capita form, because Michaely does, but this is not essenial to the argument. 
of per capita exports $(x-p)$ will change the output growth rate $(y-p)$ in the same direction even if it causes no change at all in the growth rate of the other components of output $(f-p)$. He suggests that the appropriate test is to correlate the growth rate of per capita output $(y-p)$ with the growth rate of the share of exports in the national product $(x-y)$. But eq. (2) can be easily rewritten as a slightly different identity, embodying $(x-y)$ as a linear component:

$$
y-p=(f-p)+\frac{(X / Y)}{1-(X / Y)}(x-y) .
$$

Unfortunately, Michaely's criticism also applies to his own test. Any change in the growth rate of the export share of output $(x-y)$ will change the out growth rate $(y-p)$ in the same direction even if it causes no change at all in the growth rate of the other components of output $(f-p)$.

Since what we are interested in is knowing how the growth of exports is related to the growth of the nonexport components of output, the correct correlation is between $(x-p)$ and $(f-p) .^{3}$ We use Michaely's data on average per annum growth rates between 1950-1973 and his sample of 41 LDCs. $^{4}$ The coefficient of the Spearman rank correlation between $(x-p)$ ard $(f-p)$ is $0.452,5$ which is not only significant at the one percent level but quite a bit higher than Michajely's spurious correlation (of 0.380 ).

Paralleling Michaely's investigation, we also separated the sample into the 'richer' and 'poorer' LDCs. ${ }^{6}$ The rank correlation coefficient is 0.568 for the richer group and 0.097 for the poorer group. This supports Michaely's finding that a minimum threshold of development is needed before export growth and economic growth are associated.

Finally, Michaely examines the correlation between the per capita output growth rate and the level (as opposed to the rate of change) of the axport share of GNP. This is also an inappropriate correlation, for Michaely's own reason, as reference to eq. (3) demonstrates. ${ }^{7}$ But the correlation coefficient between $(x-p)$ and $(f-p)$ is 0.578 for the 28 countries with a mean export share $(X / Y)$ below 23 percent and is -0.022 for the 13 countries with higher mean export shares. 8

\footnotetext{
${ }^{3}$ Note two phrases in this sentence. One, 'is related to' does not mean causes. And two, "the correct correlation' does not mean the correct test of a causative relationship.

4The variables we use are readily derived from those given in table 1 of Michsely (1977, p. $51 \%$.

SIcentical to the correlation coefficient to three decimal places.

6Tte dividing line is $\$ 300$ per capita output. We wero unable to locate Michily's 1972 data and ased 1973 [I.B.R.D. (1976, pp. 496ff.)]. As a result, there are 24 countries in the 'richer' saryyle (as opposed to Michaeiy's 23).

7 Also, Michaely's reported coefficient of rank correlation is incorrect. It should be -0.034, quite insignificant (not the significant $\mathbf{- 0 . 3 2 6}$ he reports (p. 52)).

The rank correlation coeffeient between $(x-p)$ and $(f-p)$ is even higher, 0.741 , for the 14 countries of the sample with the lowest export shires.
} 
This suggests that export and nonexport-output growth rates are most highly correlated - and only significantly correlated - for the relatively rich LDCs with low export shares. But the reason the data imply this is that there are seven quite unusual observations in the sampled 41 countries; these seven recorded, over 1950-1973: (i) annual growth rates of exports per capita above 7 percent; (ii) annual growth rates of nonexport-output per capita above $3 \frac{1}{2}$ percent; (iii) 1972 GNP ger capita above $\$ 300$, largely as a result of (i) and (ii); and (iv) mean export shares below 23 percent, despite (i) and partly bece.use of (ii). Studies like this nay really be just telling us that the growth rates and development patterns since World War II of Greece, Israel, Portugal, South Korea, Spain, Taiwan, and Yugoslavia are very difierent from the other 34 countries in the sample. Then again, they may be saying sornething about the less spectacular development process of the other 34 countries. For them, higher growth rates of exports did not mean lower growth rates of domestically produced output for internal final demand (the rank correlation coefficient between $(x-p)$ and $(f-p)$ for these 34 is still positive, 0.170 ). Could exports be that free lunch economists have long sought?

\section{References}

I.B.R.D., 1976, World tables 1976 (Johns Hopkins Press, Baltimore).

M. Michaely, 1977, Exports and growth: An empirical investigation, Journal of Development Economies 4, no. 1, March, 49-54. 